\title{
Total Antioxidant Capacity of Labdane and Pimarane Diterpenoids of Juniperus phoenicea $\mathrm{L}$
}

\author{
Khadija O. Badahdah \\ Chemistry Department, Girls \\ Section, Faculty of Science, \\ KAU, Jeddah, Saudi Arabia
}

\author{
Hanaa M. Ahmed \\ Plant Protection Res. Inst., \\ Mansoura branch, Agricul. \\ Res. Center, Egypt \\ M. Abdel-Mogib \\ Chem. Dept., Fac. of Sci., \\ Mansoura University \\ Mansoura, Egypt
}

\author{
Fatema B. Alamri \\ Chemistry Department, \\ Girls Section, Faculty of \\ Science, KAU, Jeddah, \\ Saudi Arabia
}

\begin{abstract}
Although Juniperus phoenicea L is a widely distributed wild tree in the south of Saudi Arabia, but its phytochemical and physiological evaluation is still poor. The chromatographic separation of the $\mathrm{CH}_{2} \mathrm{Cl}_{2} / \mathrm{MeOH}$, $1: 1$ extract of $J$, phoenicea $\mathrm{L}$. fruits gave $\beta$-sitosterol, stigmasterol, four labdane and two pimarane diterpenoids, including new labdane diterpenoid. Additionally, the volatile compounds of the main petroleum ether extract, as well as the steam-volatile constituents were identified by GC/MS. The separated compounds were identified by spectral tools. The new diterpenoid was identified as 5,9,10-triepicupressic acid.

A previous false identification of sandracopimaric acid, from the fruits of Juniperus phoenicea L. grown in Egypt, was detected and declared to be revised.

Total antioxidant capacity of extracts was estimated using total antioxidant capacity kit of Biodiagnostic, based on Koracevic et al., for biological fluids, with slight modification to suit extracts. Ascorbic acid was used as a reference antioxidant compound. Reasonable results were obtained by applying the modified method on petroleum ether extract, methylene chloride extract and ethyl acetate extract of Juniperus phoenicea L.
\end{abstract}

Keywords: Juniperus phoenicea L.; labdane diterpenoids; pimarane diterpenoids; 5,9,10-triepi-cupressic acid; total antioxidant capacity.

\section{INTRODUCTION}

Different extracts of Juniperus phoenicea L. were found to be highly physiologically active. Oils of berries and leaves showed very high cytotoxic activities against many cell lines. Additionally, the antimicrobial activity and minimum inhibitory concentration of leaf and berry oils showed high activity against most of the tested strains $[1,2]$. The essential oils obtained by supercritical fluid extraction at different pressures were active as antiviral, antiproliferative and antimicrobial [3]. The antioxidant activity by using DPPH and ABTS assays of J. phoenicia was determined $[5,4]$.

J. phoenicea leaf extracts show a remarkable effect in enhancing liver and kidney functions and may thus be of therapeutic potential in treatment hepatotoxicity and nephrotoxicity [6].

The aqueous extract of $J$. phoenicia caused a dose dependent protection of rats against castor oil induced diarrhoea and reduced castor oil induced enteropooling. The extract also caused a dose dependent decrease in intestinal transient and showed a significant dose dependent relaxant effect on rat ileal smooth muscle [7].

Many phytochemical investigations of J. phoenicea indicated the separation of essential oils $[1,3,4,8]$, labdane and pimarane diterpenoids, with remarkable unsaturation [2, 9], furanone glucosides [10, 11], and phenyl propanoids [9, 12, 13]. Although many chemical research publications were found on $J$. phoenicea, from diverse countries; Tunisia $[4,5,8]$, Morocco [9], Egypt [1], Italy [3], and France [1013], but only one research publication was found on J. phoenicea from Saudi Arabia [14], which has reported the isolation of some sesquiterpenes and diterpenes. In this research article, we aimed to phytochemically and physiologically reinvestigate $J$. phoenicea. We could report the isolation of four labdane and two pimarane diterpenoids, including a new labdane diterpenoid, in addition to the identification of the volatile compounds of petroleum ether extract by GC/MS. Additionally, 
the total antioxidant capacity of extracts was estimated using total antioxidant capacity kit of Biodiagnostic, based on Koracevic et al. [15], for biological fluids, with slight modification to suit extracts.

\section{EXPERIMENTAL}

\subsection{General}

${ }^{1} \mathrm{H}$ NMR spectra were taken on Bruker $600 \mathrm{MHz}$ at King Fahd Center for Medicinal Research, KAU, Jeddah, Saudi Arabia; GC/MS analysis was performed on A Perkin Elmer Clarus 500 GC-MS (Perkin Elmer, Shelton, CT, USA). The software controller/integrator was TurboMass version 5.4.2.1617. An Elite-1 GC capillary column, Crossbond ${ }^{\circledR} 100 \%$ dimethyl polysiloxane (30-meter $\times 0.25 \mathrm{~mm}$ ID $\times 0.25 \mu \mathrm{m} \mathrm{df}$, Perkin Elmer) was used. The carrier gas was helium (purity 99.9999\%) and flow rate was $0.9 \mathrm{~mL} / \mathrm{min}$. Source (EI+): source temperature, $270^{\circ} \mathrm{C}$. GC line temperature was $210^{\circ} \mathrm{C}$. Electron energy was $70 \mathrm{eV}$, and trapemission was $100 \mathrm{v}$. The oven was programmed as follows: initial temperature was $100^{\circ} \mathrm{C}$ (hold $2 \mathrm{~min}$ ) to $250^{\circ} \mathrm{C}$ (rate ${ }^{\circ} 15 \mathrm{C} / \mathrm{min}$, hold $4.0 \mathrm{~min}$ ). The injector temperature was $260^{\circ} \mathrm{C}$. The MS scan was from 40 to $500 \mathrm{~m} / \mathrm{z}(500 \mathrm{scan} / \mathrm{sec})$. The injection volume was $1.0 \mu \mathrm{L}$, and the Split ratio was $.40: 1$ Samples were acquired by applying the total ion chromatogram (TIC) scan modes. An average TIC scan of each peak, at definite retention times, was saved using the TurboMass software to characterize the closed peaks obtained from the MS chromatogram of the analyzed samples. The screwcapped (PTFE/silicon) 1-ml autosampler vials (12 $\mathrm{mm} \times 32 \mathrm{~mm}$ ) used for recovery were purchased from Waters (Milford, MA, USA).

\subsection{The plant material}

Juniperus phoenicea $\mathrm{L}$. fruits were collected from Nemas City, near Abha, KSA, in August 2012 by the third Author, and identified by Faraj Elghamdi, Assistant Professor of Plant Taxonomy, Botany Department, Faculty of Science, KAU, Saudi Arabia. A voucher specimen was deposited under the number HKAU 1791 in the Herbarium of the Biology Department, Faculty of Science, King Abdulaziz University.

\subsection{Processing of the plant material}

The dried and grinded fruits, $377 \mathrm{~g}$, were extracted by soaking at room temperature in $\mathrm{CH}_{2} \mathrm{Cl}_{2} / \mathrm{MeOH}$, $1: 1,1800 \mathrm{~mL}$. The $\mathrm{CH}_{2} \mathrm{Cl}_{2} / \mathrm{MeOH}$ extract was obtained by filtration and washing the plant material with $\mathrm{CH}_{2} \mathrm{Cl}_{2} / \mathrm{MeOH}$ mixture, $240 \mathrm{ml}$. The collected filtrate was left in fume cupboard with suction for overnight to be concentrated to its $1 / 4$ volume. Dilution with water, $200 \mathrm{ml}$, and exhaustive solvent extraction, using a separatory funnel, by petroleum ether $\left(40-60^{\circ} \mathrm{C}\right)$, followed by $\mathrm{CH}_{2} \mathrm{Cl}_{2}$, then $\mathrm{AcOEt}$ and finally $\mathrm{n}-\mathrm{BuOH}$ gave the crude extracts Jp1, $13.6 \mathrm{~g}$, Jp2, $1.6 \mathrm{~g}, \mathrm{Jp} 3,17.4 \mathrm{~g}$ and $\mathrm{Jp} 4,7.03 \mathrm{~g}$, respectively.

\subsection{Separation of compounds}

The pet. ether extract, Jp1, $5.6 \mathrm{~g}$ of which, was steam distilled. The distillate was extracted with diethyl ether and the ether extract was dried over anhydrous $\mathrm{Na}_{2} \mathrm{SO}_{4}$ to give the steam volatile fraction, Jp1a, $220 \mathrm{mg}$, which was analysed by GC/MS. A sample from the pet. ether extract, Jp1 was analysed by GC/MS. The steam nonvolatile material left in the distillation flask was extracted with diethyl ether and the ether extract was dried over anhydrous $\mathrm{Na} 2 \mathrm{SO} 4$ to give the steam nonvolatile fraction, Jp1b, $2.34 \mathrm{~g}$.

The non-volatile fraction, Jp1b, was separated on silica gel CC, eluted with pet. ether $(40-60 \mathrm{oC})$ then pet. ether containing increased amounts of diethyl ether. The fractions 4 and 5 (out of 5), eluted by $2 \%$ ether in pet. ether and 1, 2 and 3 (out of 6), eluted by $5 \%$ ether in pet. ether, $267 \mathrm{mg}$, contained a mixture of 1 and 4 (4:1). The fraction 1 (out of 5), eluted by $10 \%$ ether in pet. ether, $14 \mathrm{mg}$, contained a mixture of 1,5 and 6 (6:3:1). The fraction 4 (out of 11), eluted by $20 \%$ ether in pet. ether, $70 \mathrm{mg}$, contained 3. The fraction 10 (out of 11 ), eluted by $20 \%$ ether in pet. ether, $10 \mathrm{mg}$, contained $\beta$-sitosterol, and stigmasterol, (1:1).

The $\mathrm{CH} 2 \mathrm{Cl} 2$ extract, Jp2, contained main component 2 , which was purified by TLC (silica gel, diethyl ether/petroleum ether 1:50, Rf 0.72). To get rid of Na2SO4 crystals from AcOEt extract, as well as to fractionate it, it was loaded on $100 \mathrm{~g}$ silica gel (0.063-0.200 mm)/alumina, 1:2, in an addition funnel, and eluted by $\mathrm{CHCl} 3 /$ pet. ether, $3: 1$, then $\mathrm{CHCl} 3$ and finally $5 \% \mathrm{MeOH}$ in $\mathrm{CHCl} 3$ to give two fractions Jp31 and Jp32, 110 and $59 \mathrm{mg}$, respectively. The fraction Jp31 gave by TLC (silica gel, diethyl ether/petroleum ether 1:50) compound 2 (110 mg, Rf 0.5). The fraction Jp32 contained fats (saturated fatty acids). The n-BuOH extract, Jp4, contained sugars and glycolipids.

\subsection{The GC/MS analysis}

The pet. ether extract, Jp1, gave by GC/MS $\alpha$ thujene (Rt $3.05 \mathrm{~min}, 0.5 \%$ ), $\alpha$-pinene (Rt $3.14 \mathrm{~min}$, $4.8 \%$ ), sabenene (Rt 3.49 min, $1.4 \%$ ), $\beta$-pinene (Rt $3.55 \mathrm{~min}, 1.2 \%$ ), 3-carene (Rt $3.90 \mathrm{~min}, 1.9 \%$ ), bornyl acetate (Rt $6.64 \mathrm{~min}, 1.0 \%$ ), 4-terpenyl acetate (Rt $7.13 \mathrm{~min}, 1.2 \%$ ), $\alpha$-terpenyl acetate (Rt $7.22 \mathrm{~min}, 3.6 \%$ ), $\alpha$-cubebene (Rt $7.38 \mathrm{~min}, 1.0 \%$ ), $\beta$-cedrene (Rt $7.92 \mathrm{~min}, 1.7 \%$ ), cedrol (Rt $9.45 \mathrm{~min}$, $3.3 \%$ ), geranyl geraniol (Rt $12.55 \mathrm{~min}, 4.3 \%$ ), a mixture of 1, 2, 3 (Rt $13.72 \mathrm{~min}, 10.4 \%$ ), a mixture of 4, 5 (Rt $14.48 \mathrm{~min}, 28.4 \%$ ), and 6 (Rt $14.85 \mathrm{~min}$, $35.5 \%)$. The steam-volatile fraction of pet. ether extract, Jp1a, gave by GC/MS trans citral (Rt 5.55 min, 0.9\%), terpinen-4-ol (Rt $5.59 \mathrm{~min}, 0.9 \%$ ), $\alpha$ terpineol (Rt $5.65 \mathrm{~min}, 1.6 \%$ ), bornyl acetate (Rt $6.64 \mathrm{~min}, 1.8 \%$ ), $\alpha$-terpenyl acetate (Rt $7.13 \mathrm{~min}$, $0.5 \%$ ), $\beta$-cedrene (Rt $7.92 \mathrm{~min}, 1.4 \%$ ), cedrol (Rt $9.45 \mathrm{~min}, 4.5 \%$ ), $\alpha$-cadinol (Rt $9.79 \mathrm{~min}, 1.8 \%$ ), geranyl linalool (Rt $12.19 \mathrm{~min}, 4.1 \%$ ), Z,E,Egeranyl geraniol (Rt $12.30 \mathrm{~min}, 3.2 \%$ ), E,E,Egeranyl geraniol (Rt $12.55 \mathrm{~min}, 18.2 \%$ ), linoleic acid (Rt $13.21 \mathrm{~min}, 2.3 \%$ ), linolenic acid (Rt 13.29 
min, 2.3\%), stearic acid (Rt $13.70 \mathrm{~min}, 11.4 \%$ ) unknown fatty acid (Rt $13.99 \mathrm{~min}, 6.8 \%$ ), unknown fatty acid (Rt $14.71 \mathrm{~min}, 7.7 \%$ ), unknown fatty acid (Rt $15.61 \mathrm{~min}, 12.7 \%$ ), unknown fatty acid (Rt $16.70 \mathrm{~min}, 14.5 \%$ ).

\subsection{5,9,10-triepi-cupressic acid, 3:}

Amorphous material, ${ }^{1} \mathrm{H}$ NMR: $\delta 5.90,1 \mathrm{H}$, dd (17.4, 10.8), H-14, 5.21, 1H, dd $(17.4,1.2) ; 5.06$, $1 \mathrm{H}$, dd $(10.8,1.2), \mathrm{H}-15, \mathrm{H}-15$ ', $1.27,3 \mathrm{H}$, br s, H$16,4.83,1 \mathrm{H}$, br s $; 4.49,1 \mathrm{H}$, br s, H-17, H-17', 1.23, $3 \mathrm{H}, \mathrm{s}, \mathrm{H}-18,0.59,3 \mathrm{H}, \mathrm{s}, \mathrm{H}-20 ;{ }^{13} \mathrm{C}$ NMR: d 39.35 , C-1, 20.10, C-2, 38.20, C-3, 44.39, C-4, 56.57, C-5, 26.29, C-6, 38.94, C-7, 148.30, C-8, 56.72, C-9, 40.89, C-10, 18.13, C-11, 41.58, C-12, 73.96, C-13, 145.23, C-14, 111.95, C-15, 29.23, C-16, 106.78, C17, 28.30, C-18, 183.60, C-19, 12.95, C-20.

\subsection{Total Antioxidant Capacity}

Total antioxidant capacity of extracts was estimated using total antioxidant capacity kit of Bio-diagnostic [16], based on Koracevic et al. [15], for biological fluids, with slight modification to suit extracts.

\subsection{Reagents}

Substrate $\left(\mathrm{H}_{2} \mathrm{O}_{2}, \mathrm{R} 1\right.$ from Bio-diagnostic)

Chromogen (3,5-dichloro-2-hydroxybenzene sulphonate, R2 from Bio-diagnostic)

Enzyme-Buffer (superoxide dismutase - Sodium phosphate buffer: $100 \mathrm{mmol} / \mathrm{litre}, \mathrm{pH} 7.4$, R3 from Bio-diagnostic)

\subsection{Procedure}

R1 was diluted with distilled water (1:1000) immediately before use $(10 \mu \mathrm{R} 1$ was mixed with $10 \mathrm{ml}$ distilled water). Equal volumes of R2 and R3 were mixed immediately before use (working reagent). The sample, $50 \mathrm{mg}$, was dissolved in methanol, $10 \mathrm{ml}$ (pet. ether extract, $\mathrm{CH}_{2} \mathrm{Cl}_{2}$ extract, AcOEt extract). Ascorbic acid, as a reference antioxidant compound, $50 \mathrm{mg}$, was dissolved in methanol, $10 \mathrm{ml}$.

A blank experiment was conducted by mixing $20 \mu \mathrm{l}$ distilled water and $0.5 \mathrm{ml}$ diluted $\mathrm{R} 1$, standing 10 minutes, adding $0.5 \mathrm{ml}$ of working reagent, standing 5 minutes, dilution with $1 \mathrm{ml}$ distilled water and reading the absorption at $512 \mathrm{~nm}$.

Ascorbic acid solution experiments were conducted by mixing $20,10,5 \mu \mathrm{l}$, separately, with $0.5 \mathrm{ml}$ diluted R1, standing 10 minutes, adding $0.5 \mathrm{ml}$ of working reagent, standing 5 minutes, dilution with 1 $\mathrm{ml}$ distilled water and reading the absorption at 512 nm.

Sample experiments were conducted by mixing 40 , 20, 10, $\mu$ l solution, separately, with $0.5 \mathrm{ml}$ diluted $\mathrm{R} 1$, standing 10 minutes, adding $0.5 \mathrm{ml}$ of working reagent, standing 5 minutes, dilution with $1 \mathrm{ml}$ distilled water and reading the absorption at 512 $\mathrm{nm}$.

\subsection{Calculation}

$\%$ Inhibition $=[(\mathrm{AB}-\mathrm{AS}) / \mathrm{AB}] \mathrm{x} 100$

where: $A B$ is the absorbance of the blank sample, and AS is the absorbance of tested extract.

\section{RESULTS AND DISCUSSIONS}

The chromatographic separation of the extract of $\mathbf{J}$. phoenicea L. fruits gave $\beta$-sitosterol, stigmasterol, four labdane 1-4 and two pimarane diterpenoids, 5 and 6 , including a new labdane diterpenoid, 3 . Additionally, the volatile compounds of the main petroleum ether extract, as well as the steam-volatile constituents were identified by GC/MS.

Compound 1 as E-communic acid was isolated previously from Juniperus taxifolia by Muto et al. [17]. Compound 2 was identified as 13-epitorulosal, isolated previously from Juniperus rigida by Woo et al. [18]. Compound 4 was identified as 15-norlabda12,(17)8-E-diene 14-carboxaldehyde 19-carboxylic acid, isolated previously from Platycladus orientalis by Kuo and Chen [19]. Compound 6 was identified as isopimara-7-en-18oic acid, isolated previously from Pinus armandii heartwood [20]. Compound 5 as sandracopimaric acid was identified by spectral data and confirmed by comparing ${ }^{1} \mathrm{H}$ NMR data with the corresponding compound isolated previously from Juniperus taxifolia [17] and with the 4-epimer, isolated previously from Illicium jiadifengpi [21]. In the 4epimer, the methyl group (C-18) absorbs at 1.26 ppm instead of 1.21 for the methyl group (C-19). Sandracopimaric acid 5 and 4-episandracopimaric acid differ also in the chemical shift value of the methyl group (C-20), where in the former it absorbs at $0.84 \mathrm{ppm}$, versus 0.73 in case of the 4 -epimer [21]. El-Sawi and Motawe [2] reported a diterpenoid as sandracopimaric acid from the fruits of Juniperus phoenicea L. grown in Egypt. They reported $\mathrm{H}-14, \mathrm{H}-15, \mathrm{H}-16$ and $\mathrm{H}-20$ at unjustified $\mathrm{d}$ values of $6.85,3.59,4.20$ and $1.59 \mathrm{ppm}$, respectively. The identification of this compound is doubtful and should be revised. Compound 3 was separated from fraction 4 of the pet. ether nonvolatile fraction, Jp1b, eluted by $20 \%$ ether in pet. ether. It gave $\mathrm{M}+\mathrm{at} \mathrm{m} / \mathrm{z} 320$, in agreement with $\mathrm{C}_{20} \mathrm{H}_{32} \mathrm{O}_{3}$. The structure of 3 was elucidated by ${ }^{1} \mathrm{H}$ NMR. The $1 \mathrm{H}$ NMR spectrum of 3 (Table 1) was almost similar to that of 2 , with the aldehydic proton signal no longer present and the methyl signal of C18 shifted down-field from 0.97 in 2 to $1.23 \mathrm{ppm}$ in 3 , in agreement with 19-carboxylic acid. The good co-incidence between the signals of the side chain (H-14, H-15, H-15, H-16) in both compounds (2 and 3) indicated the same constitution of the sidechain at C-9 (Table 1). Comparing the ${ }^{1} \mathrm{H}$ NMR data of 3 with those of 13-epi-cupressic acid [18], 4,13diepi-cupressic acid [22] and 4-epi-cupressic acid [23] indicated that H-16 in 13-epi-cupressic acid [18] shifted up-field by $0.09 \mathrm{ppm}$. Thus, the opposite configuration at $\mathrm{C}-13$ is more probable.

Comparing the ${ }^{13} \mathrm{C}$ NMR data of 3 with those of 13epi-cupressic acid [18] (Table 2) indicated obvious shifts in $\delta_{C}$ values of C-4, C-5, C-6 (- 0.29, - 0.17, +0.11 , respectively), as well as those of C-10, C-20 (- $0.49,-0.75$, respectively) and those of $\mathrm{C}-13, \mathrm{C}-16$ 
(- 0.96, +0.47 , respectively). This indicated more probably the opposite configuration at $\mathrm{C}-5, \mathrm{C}-10$ and $\mathrm{C}-13$. Comparing the ${ }^{13} \mathrm{C}$ NMR data with those of 4-epi-cupressic acid [23] (Table 2) indicated obvious shifts in $\delta_{\mathrm{C}}$ values of C-5, C-6 (- $6.17,+$ 1.21 , respectively), as well as those of C-10, C-20 ($1.09,+2.25$, respectively) and those of C-3, C-4, $\mathrm{C} 18, \mathrm{C} 19+0.60,+3.51,-10.70,-2.30$, respectively). This indicated more probably the opposite configuration at C-5, C-10 and C-4.

The NOESY experiment showed clear noe effects between $\mathrm{H}-20, \mathrm{H}-17, \mathrm{H}-17$ ', H-16, H-18, H-11, H2 $\alpha$ and $\mathrm{H} 7 \alpha$, as well as between $\mathrm{H} 16, \mathrm{H} 18, \mathrm{H}-14, \mathrm{H}-15$, $\mathrm{H}-17, \mathrm{H}-7 \alpha$ and $\mathrm{H}-11$. Thus 3 was identified as 5,9,10-triepicupressic acid.

The total antioxidant capacity considers the cumulative effect of all antioxidants present. Total antioxidant capacity of extracts was estimated using total antioxidantcapacity kit of Bio-diagnostic [16], based on Koracevic et al. [15], for biological fluids, with slight modification to suit extracts. Ascorbic acid was used as a reference antioxidant compound. Reasonable results were obtained by applying the modified method on petroleum ether extract, methylene chloride extract and ethyl acetate extract of J. phoenicea L.

Table 3 indicated the volumes taken from petroleum ether extract, methylene chloride extract and ethyl acetate extract of $J$. phoenicea $\mathrm{L}$. and the corresponding absorptions at $512 \mathrm{~nm}$. It is clear that as the quantity of extract increased, the $(\cdot \mathrm{OH})$ inhibition\% increased and the absorption at $512 \mathrm{~nm}$ decreased. Table 4 and figure 2 indicated the $(\cdot \mathrm{OH})$ free radical inhibition $\%$ of ascorbic acid at concentrations $100,50,25 \mu \mathrm{g} / \mathrm{ml}$. Table 5 and figure 3 indicated the $(\mathrm{OH})$ free radical inhibition $\%$ of petroleum ether, methylene chloride and ethyl acetate extracts of $J$. phoenicea L. at concentrations $200,100,50 \mu \mathrm{g} / \mathrm{ml}$. A remarkable increase of $(\mathrm{OH})$ inhibition \% happened when the concentration of the extract has been risen from 50 to $100 \mu \mathrm{g} / \mathrm{ml}$. After that, the duplication of the extract concentration from 100 to $200 \mu \mathrm{g} / \mathrm{ml}$ has a little effect on the (.OH) inhibition \%.

If we take into account that the molar mass of ascorbic acid is $176 \mathrm{~g} / \mathrm{mol}$, while average molar mass of J. phoenicea diterpenoids is about 310 $\mathrm{g} / \mathrm{mol}$; and also that extracts are not pure diterpenoids, we will realize that the J. phoenicea diterpenoids have remarkable total antioxidant capacity. The total antioxidant capacity of $J$. phoenicea diterpenoids could be attributed to the large unsaturation that accommodates the free radicals.

\section{ACKNOWLEDGEMENTS}

Chemistry Department at Faculty of Science, KAU, is acknowledged for providing the research facilities. The authors are indebted to Prof. Alaa Khedr, Faculty of Pharmacy, King Abdulaziz University, for GC/MS analysis.

Table 1: ${ }^{1} \mathrm{H}$ NMR data ( $600 \mathrm{MHz}, \mathrm{CDCl}_{3}, \delta$ value, multiplicity ( $\mathrm{J}$ value in $\mathrm{Hz}$ )) of 5,9,10-triepi-cupressic acid (3), compared with those of 2, 13-epi-cupressic acid [5], 4,13-diepi-cupressic acid [10] and 4-epi-cupressic acid [11].

\begin{tabular}{|c|c|c|c|c|c|}
\hline $\begin{array}{l}\text { H-atom } \\
\text { number }\end{array}$ & $\begin{array}{l}{ }^{1} \mathrm{H} \text { NMR data of } \\
\text { compound } 3\end{array}$ & Compound 2 & $\begin{array}{l}\text { 13-Epi-cupressic } \\
\text { acid }\end{array}$ & $\begin{array}{l}\text { 4,13-Diepi- } \\
\text { cupressic acid }\end{array}$ & $\begin{array}{l}\text { 4-Epi-cupressic } \\
\text { acid }\end{array}$ \\
\hline 14 & $\begin{array}{l}5.90,1 \mathrm{H}, \mathrm{dd} \\
(17.4,10.8)\end{array}$ & $\begin{array}{l}5.90,1 \mathrm{H}, \mathrm{dd} \\
(17.2,10.8)\end{array}$ & $\begin{array}{l}5.88,1 \mathrm{H}, \mathrm{dd} \\
(17.0,10.5)\end{array}$ & $\begin{array}{l}5.81,1 \mathrm{H}, \mathrm{dd}(17.2, \\
10.8)\end{array}$ & $\begin{array}{l}5.92,1 \mathrm{H}, \mathrm{dd}(17, \\
10)\end{array}$ \\
\hline $15,15^{\prime}$ & $\begin{array}{l}5.21,1 \mathrm{H}, \mathrm{dd} \\
(17.4,1.2) ; 5.06, \\
1 \mathrm{H}, \mathrm{dd}(10.8,1.2)\end{array}$ & $\begin{array}{l}5.21,1 \mathrm{H}, \text { br } \\
\mathrm{d}(17.2) ; 5.06,1 \mathrm{H}, \\
\text { br d(10.8) }\end{array}$ & $\begin{array}{l}5.18,1 \mathrm{H}, \mathrm{dd} \\
(18.0,2) ; 5.02, \\
1 \mathrm{H}, \operatorname{dd}(10.5,2)\end{array}$ & $\begin{array}{l}5.13,1 \mathrm{H}, \mathrm{d}(17.2) \\
4.98,1 \mathrm{H}, \mathrm{d}(10.8)\end{array}$ & $\begin{array}{l}5.20,1 \mathrm{H}, \text { br d(17); } \\
5.07,1 \mathrm{H}, \text { br d(10) }\end{array}$ \\
\hline 16 & $1.27,3 \mathrm{H}$, br s & $1.27,3 \mathrm{H}, \mathrm{s}$ & $1.18,3 \mathrm{H}, \mathrm{s}$ & $1.22,3 \mathrm{H}$, br s & $1.26,3 \mathrm{H}, \mathrm{s}$ \\
\hline $17,17^{\prime}$ & $\begin{array}{l}4.83,1 \mathrm{H}, \text { br s } \\
4.49,1 \mathrm{H}, \text { br s }\end{array}$ & $\begin{array}{l}4.87,1 \mathrm{H}, \text { br s} \\
4.53,1 \mathrm{H}, \mathrm{br} \mathrm{s}\end{array}$ & $\begin{array}{l}4.82,1 \mathrm{H}, \mathrm{s} ; 4.51, \\
1 \mathrm{H}, \mathrm{s}\end{array}$ & $\begin{array}{l}4.79,1 \mathrm{H}, \mathrm{s} ; 4.48 \\
1 \mathrm{H}, \mathrm{s}\end{array}$ & $\begin{array}{l}4.84,1 \mathrm{H}, \text { br s; } 4.52 \\
1 \mathrm{H}, \text { br s }\end{array}$ \\
\hline 18 & $1.23,3 \mathrm{H}, \mathrm{s}$ & $0.97,3 \mathrm{H}, \mathrm{s}$ & $1.22,3 \mathrm{H}, \mathrm{s}$ & - & - \\
\hline 19 & - & $9.74,1 \mathrm{H}, \mathrm{s}$ & - & $1.18,3 \mathrm{H}, \mathrm{s}$ & $1.13,3 \mathrm{H}, \mathrm{s}$ \\
\hline 20 & $0.59,3 \mathrm{H}, \mathrm{s}$ & $0.56,3 \mathrm{H}, \mathrm{s}$ & $0.61,3 \mathrm{H}, \mathrm{s}$ & $0.54,3 \mathrm{H}, \mathrm{s}$ & $0.70,3 \mathrm{H}, \mathrm{s}$ \\
\hline
\end{tabular}

Table 2: ${ }^{13} \mathrm{C}$ NMR data $\left(150.9 \mathrm{MHz}, \mathrm{CDCl}_{3}, \delta\right.$ value, multiplicity) of 5,9,10-triepi-cupressic acid (3), compared with those of 13-epi-cupressic acid [5] and 4-epi-cupressic acid [11].

\begin{tabular}{|l|l|l|l|}
\hline $\begin{array}{l}\text { C-atom } \\
\text { number }\end{array}$ & $\begin{array}{l}{ }^{13} \mathrm{C} \text { NMR } \\
\text { data of } \\
\text { compound } \mathbf{3}\end{array}$ & $\begin{array}{l}\text { 13-Epi- } \\
\text { cupressic } \\
\text { acid }\end{array}$ & $\begin{array}{l}\text { 4-Epi- } \\
\text { cupressic } \\
\text { acid }\end{array}$ \\
\hline 1 & 39.35 & 39.3 & 38.0 \\
\hline 2 & 20.10 & 20.0 & 19.3 \\
\hline
\end{tabular}

www.ijsea.com

\begin{tabular}{|l|l|l|l|}
\hline 3 & 38.20 & 38.3 & 38.8 \\
\hline 4 & 44.39 & 44.1 & 47.9 \\
\hline 5 & 56.57 & 56.4 & 50.4 \\
\hline 6 & 26.29 & 26.4 & 27.5 \\
\hline 7 & 38.94 & 38.7 & 38.6 \\
\hline 8 & 148.30 & 148.6 & 148.9 \\
\hline 9 & 56.72 & 56.8 & 58.0 \\
\hline 10 & 40.89 & 40.5 & 39.8 \\
\hline 11 & 18.13 & 18.0 & 18.5 \\
\hline
\end{tabular}


International Journal of Science and Engineering Applications

Volume 4 Issue 5, 2015, ISSN-2319-7560 (Online)

\begin{tabular}{|l|l|l|l|}
\hline 12 & 41.58 & 41.5 & 42.5 \\
\hline 13 & 73.96 & 73.0 & 73.1 \\
\hline 14 & 145.23 & 145.1 & 147.3 \\
\hline 15 & 111.95 & 110.8 & 111.5 \\
\hline 16 & 29.23 & 26.7 & 29.1 \\
\hline 17 & 106.78 & 105.7 & 107.6 \\
\hline 18 & 28.30 & 28.4 & 181.3 \\
\hline 19 & 183.60 & 183.5 & 17.6 \\
\hline 20 & 12.95 & 12.2 & 15.2 \\
\hline
\end{tabular}

Table 3: The volumes taken from petroleum ether, methylene chloride and ethyl acetate extracts of $J$. phoenicea $\mathrm{L}$. and the corresponding absorptions at $512 \mathrm{~nm}$

\begin{tabular}{|c|c|c|c|}
\hline Sample & $\begin{array}{c}\text { Volume } \\
\text { taken } \\
\text { in } \boldsymbol{\mu l}\end{array}$ & $\begin{array}{c}\text { Absorption } \\
\text { at } \mathbf{5 1 2} \mathbf{~ n m}\end{array}$ & $\begin{array}{c}\text { Inhibition } \\
\text { \% }\end{array}$ \\
\hline Blank & & 0.292 & 0 \\
\hline PE extract & 40 & 0.089 & 69.5 \\
\hline & 20 & 0.095 & 67.5 \\
\hline & 10 & 0.218 & 25.3 \\
\hline $\begin{array}{c}\mathrm{CH}_{2} \mathrm{Cl}_{2} \\
\text { extract }\end{array}$ & 40 & 0.077 & 73.6 \\
\hline & 20 & 0.099 & 66.1 \\
\hline & 10 & 0.273 & 6.5 \\
\hline $\begin{array}{c}\mathrm{AcOEt} \\
\text { extract }\end{array}$ & 40 & 0.134 & 54.3 \\
\hline & 20 & 0.156 & 46.6 \\
\hline & 10 & 0.217 & 25.5 \\
\hline
\end{tabular}

Table 4: The $(\cdot \mathrm{OH})$ free radical inhibition $\%$ of ascorbic acid at concentrations $100,50,25 \mu \mathrm{g} / \mathrm{ml}$.

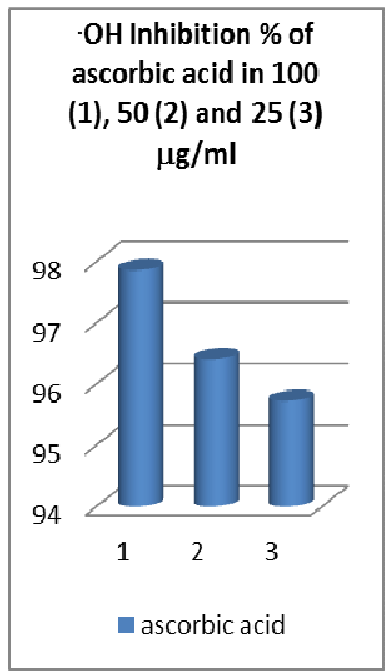

Fig 2: The $(\mathrm{OH})$ free radical inhibition $\%$ of ascorbic acid at concentrations 100, 50,25 $\mu \mathrm{g} / \mathrm{ml}$.

Table 5: The $(\mathrm{OH})$ free radical inhibition $\%$ of petroleum ether, methylene chloride and ethyl acetate extracts of $J$. phoenicea L. at concentrations $200,100,50 \mu \mathrm{g} / \mathrm{ml}$.

\begin{tabular}{|c|c|c|c|}
\hline $\begin{array}{c}\text { Conc. in } \\
\boldsymbol{\mu g} / \mathbf{m l}\end{array}$ & $\begin{array}{c}\mathbf{P E} \\
\text { extract }\end{array}$ & $\begin{array}{c}\mathbf{C H}_{2} \mathbf{C l}_{2} \\
\text { extract }\end{array}$ & $\begin{array}{c}\text { AcOEt } \\
\text { extract }\end{array}$ \\
\hline 200 & 69.5 & 73.6 & 54.3 \\
\hline 100 & 67.5 & 66.1 & 46.6 \\
\hline 50 & 25.3 & 6.5 & 25.5 \\
\hline
\end{tabular}

\begin{tabular}{|c|c|}
\hline conc. $\boldsymbol{\mu g} / \mathbf{m l}$ & ascorbic acid \\
\hline 100 & 97.86 \\
\hline 50 & 96.41 \\
\hline 25 & 95.72 \\
\hline
\end{tabular}<smiles>C=CC(C)=CC[C@H]1C(=C)CC[C@@]2(C(=O)O)[C@@]1(C)CCC[C@@]2(C)CC</smiles>

E-Communic acid (1)<smiles></smiles>

13-Epi-torulosal (2) 

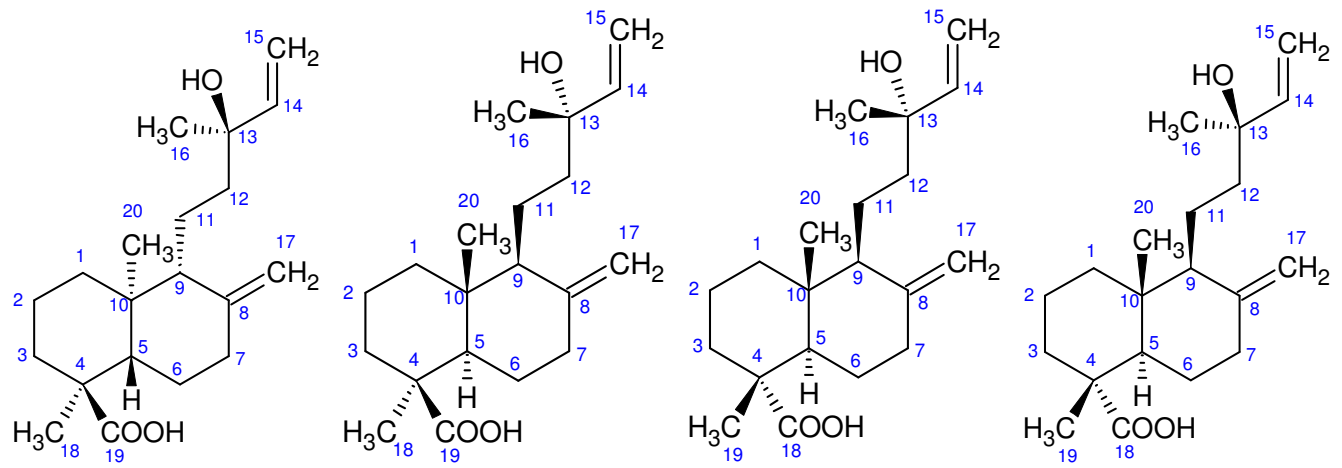

5,9,10-Triepicupressic acid (3) 13-Epi-cupressic acid 4,13-Diepi-cupressic acid 4-Epi-cupressic acid
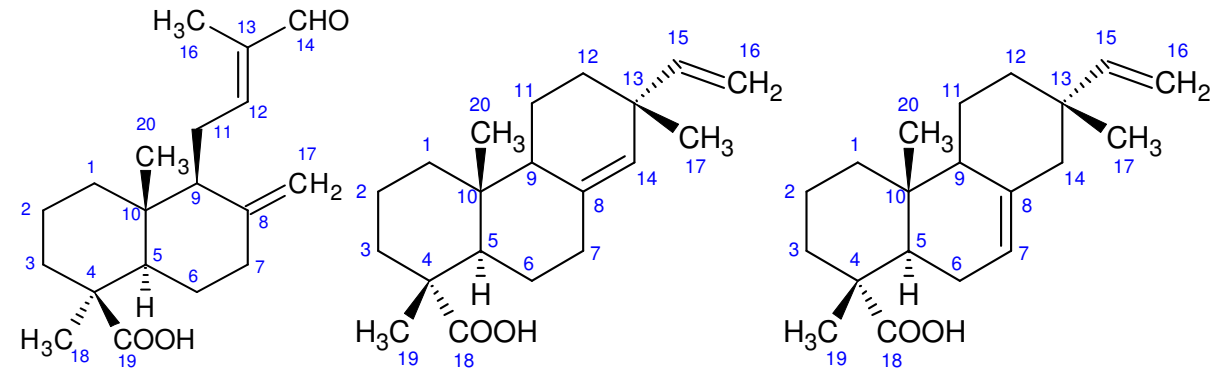

15-Norlabda-8(17),12E-diene

14-carboxaldehyde 19-

Sandracopimaric acid (5)

Isopimara-7-en-18-oic acid (6) carboxylic acid (4)

Fig. 1: Isolated diterpenoids from Juniperus phoenicea $\mathrm{L}$. fruits

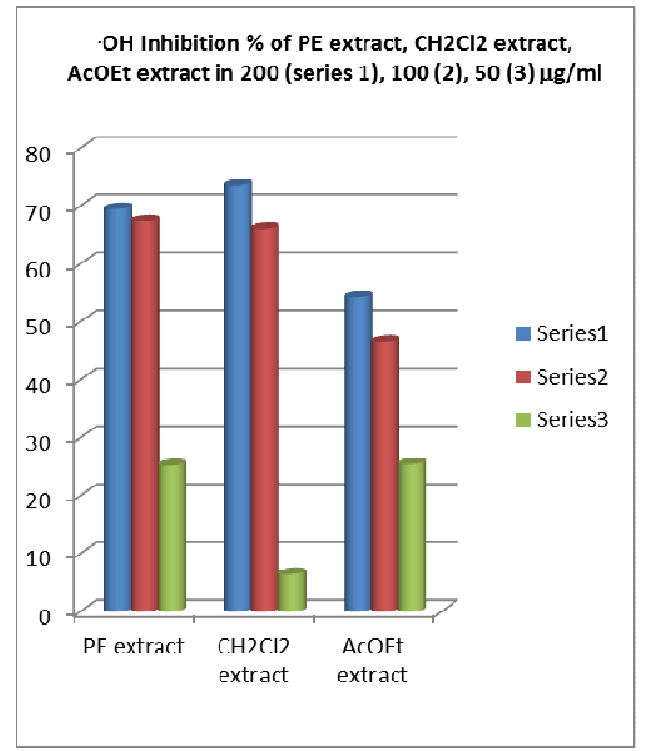

Fig 3: The (.OH) free radical inhibition \% of petroleum ether extract, methylene chloride extract and ethyl acetate extract of J. phoenicea L. at concentrations $200,100,50 \mu \mathrm{g} / \mathrm{ml}$.

\section{REFERENCES}

[1]S.A. El-Sawi, H.M. Motawae, A.M. Ali, African

J. Trad. Complement. Med. 2007, 4, 417-426.
[2]S.A. El-Sawi, H.M. Motawae, Canad. J. Pure Appl. Sci. 2008, 2, 115-122. 
International Journal of Science and Engineering Applications

Volume 4 Issue 5, 2015, ISSN-2319-7560 (Online)

[3]B. Marongiu, S. Porcedda, A. Caredda, A. Piras, L. Vargiu, L. Mascia, A. Cadeddu, R. Loddo, J. Essen. Oil Res. 2004, 16, 256-261.

[4]M. Ennajar, J. Bouajila, A. Lebrihi, F. Mathieu, M. Abderraba, A. Raies, M. Romdhane, J. Food Sci. 2009, 74, M364-371.

[5]N. Nasri, N. Tlili, W. Elfalleh, E. Cherif, A. Ferchichi, A., Khaldi, S. Triki, Nat. Prod. Res. 2011, 25, 1733-1742.

[6] S.A. Ali, M.Z. Rizk, N.A. Ibrahim, M.Sh. Abdallah, H.M. Sharara, M.M. Moustafa, World J. Gastrointest. Pharmacol. Ther. 2010, $1,123-131$.

[7]E.Y. Qnais, F.A. Bdulla, Y.Y. Abu Ghalyun, Asian Network for Scientific Information, Pakistan, 2005.

[8]H. Medini, A. Elaissi, F. Farhat, M.L. Khouja, R. Chemli, F. Harzallah-Skhiri, Chem. Biodivers. 2009, 6, 1378-1387.

[9]A.F. Barrero, J.F. Quilez del Moral, M.M. Herrador, M. Akssira, A. Bennamara, S. Akkad, M. Aitigri, Phytochemistry, 2004, 65, 2507-2515.

[10]G. Comte, D.P. Allais, A.J. Chulia, J. Vercauteren, C. Bosso, Tetrahedron Lett. 1996, 37, 2955-2958.

[11]G. Comte, D.P. Allais, A.J. Chulia, J. Vercauteren, C. Delage, Phytochemistry, 1996, 41, 1329-1332.

[12]G. Comte, A.J. Chulia, J. Vercauteren, D.P. Allais, Planta Med. 1996, 62, 88-89.
[13]G. Comte, D.P. Allais, A.J. Chulia, J. Vercauteren, N. Pinaud, Phytochemistry, 1997, 44, 1169-1173.

[14]A.M. Dawidar, S.T. Ezmirly, M. Abdel-Mogib, Pharmazie, 1991, 46, 472-473.

[15] D. Koracevic, G, Koracevic, V. Djordjevic, S. Andrejevic, V. Cosic, J, Clin. Pathol. 2001, 54, 356-361.

[16]N. Muto, T. Tomokuni, M. Haramoto, H. Tatemoto, T. Takanishi, Y. Inatomi, H. Murata, A. Inada, Biosci. Biotechnol. Biochem. 2008, 72, 477-484.

[17]K.W. Woo, S.U. Choi, J.C. Park, K.R. Lee, Arch. Pharm. Res. 2011, 34, 2043-2049.

[18] Y.H. Kuo, W.C. Chen, J. Chin. Chem. Soc. 1999, 46, 819-824.

[19]Y.X. Zhao, L. Zhou, L. Guo, X.D. Luo, J. Zhou, J. Asian Nat. Prod. Res. 2005, 7, 259 264.

[20]H. Ping, G. Karagianis, P.G. Watermam, Nat. Prod. Res. Dev. 2005, 17, 309-312.

[21]E. Abdel-Sattar, A.R. Abdel Monem, Sh.M. Ezzat, A.M. El-Halawany, S.M. Mouneir, Z. Naturforsch. 2009, 64c, $819-823$.

[22]T. Hieda, Y. Mikami, Y. Obi, T. Kisaki, Agric. Biol. Chem. 1982, 46, 2477-2484.

[23] Bio-diagnostic web page: http://www.biodiagnostic.com/ 